Seminars, Conferences, Addresses

\title{
International Symposium on Islam and Modernity
}

\section{9-21 Jumādā al Awwal 1413/ 4-6 November 1993 \\ Karachi, Pakistan}

The three-day seminar on "Islam and Modernity" was held under the joint auspices of the Goethe Institute (Karachi), the International Institute of Islamic Thought (Islamabad), and the Islamic Research Institute (Islamabad). Thirty scholars from Pakistan and four scholars from Germany participated as delegates, and an equal number of other scholars, journalists, and bureaucrats attended as observers. The seminar addressed four themes: a) The State: Legitimation and Participation; (b) The Law: Law and Justice; (c) The Economy and Finance: Economy and Ethics; and (d) Society: Equality and Justice. The sessions were arranged to give adequate time to the presenters and for follow-up discussion.

In general, the seminar sought to create a better understanding and appreciation of the current self-assertion in the Muslim world and the ways in which Muslims are dealing with modernity. There is a growing belief among Muslims that it is possible to achieve developmental goals, as well as those of material and social welfare, within the framework of Islam. This, it is believed, would save their societies from moral degradation, the breakdown of social and family structures, the dehumanization of human life, and other negative features of western modernity.

This resurgence often generates fear and apprehension in the West, a reaction that might be partially due to sporadic acts of violence by Muslim extremists. The West's perception of Islamic resurgence is thus colored, which undermines its ability to see it for what it really is. Despite this, however, many people in the West feel the need for a better understanding of the changes taking place in Muslim societies and for entering into a dialogue with their Muslim counterparts in order to explore the possibility of promoting mutual respect and creating an atmosphere of meaningful and peaceful coexistence.

In addition to the general divide between Islam and the West, there is a secular vs. Islamist divide within Muslim societies. Some adhere to the secular view of life and seek to confine religion to a private concern, while others want to restructure the individual and all elements of social life according to Islamic principles and values. 
The secular West tends to support without questions the secular forces and condemn the Islamic ones, calling the latter "Islamic fundamentalists" and trying to make it synonymous with terrorism and extremism. Many autocratic and dictatorial regimes in the Muslim world survive and perpetuate themselves by seeking support from international secularist forces by playing upon the West's fear of Islamic fundamentalism and posing as secularists.

The collapse of socialism and the dismantling of Soviet power has added another dimension to this phenomenon. Afghanistan has become free, and six Muslim republics have become independent on its border. In the heart of Europe, Albania has become free and its Muslim majority may soon assert its identity. The rise of a tiny Muslim state in Bosnia has seen the rise of a savage wave of ethnic and religious hatred in the form of a brutal and genocidal campaign perpetrated by the Serb Christians. The West's apathy and double standards has not gone unnoticed by the Muslims. This attitude, and perhaps latent hostility, can also be seen in Kashmir and other places. In part, it is due to an unfortunate perception by some western thinkers, politicians, and strategists, that the Muslim world is the potential adversary of the future.

There is, however, a large number of people on both sides of the divide who believe that the Muslim and western peoples have more in common than is generally realized. They also assert that both can live in peace and harmony in addition to cooperating in the construction of a world that is free from exploitation, injustice, and strife.

The organization of this seminar was a small step in the realization of this goal. Several research organizations and scholars from Germany and Pakistan collaborated in this venture. The participation of the German scholars provided a clue to European, and particularly German, thinking. Similarly, the German scholars had an opportunity to acquaint themselves with the views of a wide spectrum of Pakistani scholars. It was agreed that the dialogue should continue for a four-year period and that there would be an annual seminar held alternatively in Germany and Pakistan.

IIIT-Pakistan Office Islamabad, Pakistan 